\title{
K niektorým aktuálnym presahom Martího filozofie
}

\author{
Dominika Dinušová \\ Akadémia Policajného zboru v Bratislave, SK
}

DINUŠOVÁ, D.: On Some of the Actual Overlaps of Martís Philosophy

Philosophica Critica, vol. 6, 2020, no. 1, ISSN 1339-8970, pp. 67-77

The paper covers selected aspects of philosophical legacy of José Martí. It approaches Martís thought on the background of social situation in the end of the $19^{\text {th }}$ century. It deals with perceiving of Martí's works, relation between Martí's philosophy and Cuban revolution and some intersections of martianism and marxism. The main aim of this paper is to understand different interpretations of José Martís philosophy and its legacy in the view of current social processes.

Key words: José Martí - Latin America - Philosophy - Colonialism Revolution.

\section{Úvod}

Niektoré filozofické diela sú živé aj vd’aka sporom o ich charakter, obsah a spoločenský význam. Medzi ne možno zaradit' filozofické dielo José Martího, kubánskeho literáta, filozofa a bojovníka za nezávislost', ktorý pôsobil v Latinskej Amerike na konci 19 storočia. Okrem početných polemických prác, ktoré sa venovali jeho myšlienkam a formám ich spracovania, o tom svedčia i udalosti zo začiatku roka 2020. Široký spoločenský ohlas vyvolala séria vandalských útokov na pamätníky José Martího v Havane. Obrázky sôch a búst kubánskeho národného hrdinu poliate červenou farbou v deň 61. výročia kubánskej revolúcie sa na sociálnych siet'ach objavili spolu s krátkym vysvetlením a výzvou aktérov skutku : „je to výkrik vojny proti diktatúre a volanie l’udu k sprisahaniu." Rozpútala sa spoločenská debata, v ktorej opakovane a často zaznievalo pýtanie sa: Prečo Martí? Prečo na protest proti politickému zriadeniu na Kube pošpinili práve Martího? Odpoved' na tieto otázky má akiste rozmery presahujúce kubánske reálie. Sú podnetom k pýtaniu sa po samotnom Martím a jeho myšlienkovom 
odkaze. Okrem iného vytvárajú priestor pre opakovanú reflexiu Martího prínosu do filozofie, ktorá zároveň umožňuje objasnit', čo v jeho živote a diele dodnes inšpiruje, poburuje a robí z neho kontroverzného autora i pre 21. storočie. Hoc na prvý pohl'ad sa môže javit' Martího filozofia slovenskému prostrediu vzdialená, v súčasnom svete pospájanom informačnými dial'nicami nemožno rezignovat' na poznávanie iných skúseností, ktoré v konečnom dôsledku môžu viest' k pochopeniu všeobecných čŕt spoločného globálneho sociálneho prostredia.

\section{Martí ne/patrí Amerike}

José Martí je dnes na Kube považovaný za najvýznamnejšiu osobnost' tamojších dejín. Narodil sa v roku 1853 v Havane a už ako mladý sa nadchol myšlienkou kubánskej nezávislosti. Z politických dôvodov strávil niekol'ko rokov vo vyhnanstve v Európe, neskôr v latinskoamerických štátoch a v USA. Napokon sa v roku 1895 vrátil na Kubu, kde chcel realizovat' oslobodenie ostrova spod koloniálneho panstva Španielska. V jednej z bitiek medzi oslobodeneckou armádou a španielskym vojskom napokon padol.

Martího dielo vo viacerých aspektoch presahovalo už počas jeho života hranice jednoznačne vymedzenej oblasti záujmu a časového i priestorového záberu. Z hladiska vymedzenej oblasti záujmu, je José Martí dnes považovaný za významného autora literárnej moderny, básnika a napokon i revolucionára Latinskej Ameriky, no taktiež býva diskutovaný ako angažovaný politický filozof, ktorý vníma filozofiu ako významný prostriedok sociálnej praxe. Priestorový záber jeho diela možno badat' vo viacerých rovinách. Faktom je, že už počas svojho života jeho dielo presahovalo geografické hranice Kuby. Hoci bola jeho literárna, filozofická tvorba i politická aktivita zameraná na oslobodenecký boj kubánskeho územia, samotný Martí pripútaný ku Kube a k jej boju za nezávislost' prežil takmer celý život mimo tohto ostrova. To sa akiste podpísalo i pod jeho zdôrazňovanie špecifickosti historickej situácie človeka ako jedného z determinantov filozofie a napokon malo vplyv i na všeobecné rozšírenie a aplikáciu jeho myšlienkového konceptu. Z hl'adiska časového ukotvenia je Martí autorom 19. storočia, autorom buržoáznodemokratických ideálov o slobodnej republike. No ked'že na Kube došlo k boju za nezávislost' v čase, kedy v Amerike prežívali svoju jar formálne nezávislé republiky, Martí mal možnost' sledovat' spoločenské posuny v týchto krajinách smerujúce k imperializmu a vo svojich prácach upozorňoval na hrozbu neokolonializmu v Latinskej Amerike. Práve kritika neokolonializmu sa stala predmetom spoločenských bojov nasledujúce desat'ročia. Všetky tieto presahy životných reálií José Martího sa podpísali pod niektoré jedinečné črty jeho filozofickej tvorby, ktorá sa orientovala na problémy človeka v jeho konkrétnej žitej praxi. 
Črty Martího myšlienkového smerovania sa rysujú už v esejach Guatemala a La Riqueza de Guatemala, ktoré vznikli počas jeho ročného pobytu v Guatemale (1877 - 1878). Východiskom Martího úvah o situácii v Latinskej Amerike bolo tvrdenie, že Španielom sa podarilo dobyt' americké územie vd'aka nejednotnosti vládnucich vrstiev domorodého obyvatel'stva v období príchodu Španielov. Tí vedeli nejednotnost' indiánskych spoločností využit' na dosiahnutie svojich dobyvatel'ských ciel'ov. Z tohto konštatovania vyvodil Martí ústrednú líniu svojho sociálneho myslenia, ktorá prestupuje jeho filozofickou, literárnou i politickou činnostou, a to dôraz na jednotu. Prostredníctvom aspektu jednoty vykresl'uje Martí svoju víziu spoločnosti a definuje tiež revolučný boj. V prípade chápania revolúcie je dôraz na jednotu badat' v dvoch rozmeroch: jednota sa prejavuje v spájaní l'udí bez ohl'adu na rasu, vierovyznanie, etnickú príslušnost', národnost' pričom jednotiacim prvkom je boj proti kolonializmu; jednota sa prejavuje na úrovni vnímania samotného procesu revolučného t'aženia, ktoré má obsahovat' prvky nových požadovaných vztahov, resp. uplatňovanie praxe $\mathrm{v}$ rámci revolučného procesu má byt' zároveň už budovaním novej sociálnej reality.

Aby mohol Martí v praktickej činnosti uplatnit’ princíp jednoty, musí odmietnut' rasovú a etnickú nadradenost'. $\mathrm{V}$ duchu ideálov humanizmu tvrdí, že „niet rasovej nenávisti, pretože niet rás. (...) rovnaká a večná duša pramení v telách rozličných foriem a farieb. Hreší proti l'udskosti, kto podporuje a propaguje protichodnost' a nenávist' rás." (Martí 2005) Samotný rasizmus vníma ako pozostatok koloniálneho panstva, ktorého výrazom bolo otroctvo. Zotrvávat' v rasistických stanoviskách znamená pokračovat' v budovaní panstva a nadradenosti, ktorých výsledkom je vykoristovanie. V Martího interpretácii, cielené roznecovanie rasovej nenávisti ideovo obhajuje panské vztahy a zároveň slúži k triešteniu boja proti kolonializmu. Ako píše, „na bedrách (čierneho Kubánca) bola republika v bezpečí a on ju nikdy neohrozoval. Len tí, ktorí černocha nenávidia, vidia v černochovi nenávist'; a taktiež tí, ktorí sú ochotní špekulovat' s podobným nepodloženým strachom, aby touto nechutnou činnost'ou zviazali ruky, ktoré by sa mohli zdvihnút' a vyhnat' z kubánskej zeme ničivého okupanta (Martí 1985, 292). Martího kritika rasovej nadradenosti sa však nevztahuje len na černochov, no tiež na pôvodné indiánske obyvatel'stvo, ktoré rovnako znášalo pohŕdanie a ponižovanie v spoločnosti. Spolu s odmietnutím rasizmu zdôrazňuje Martí indiánsku otázku. Indiáni sú tí, na ktorých sa kolonializmus podpísal najkrutejšie, preto aj idea oslobodenia je nevyhnutne zviazaná s emancipáciou indiánov. Spolu s týmito ideami sa do Martího zorného pola dostáva významný problém novokonštituovaných národných celkov 
a Američanov 19. a 20. storočia stelesnený v otázke vlastnej identity, ktorá v danom období zostávala zhmlená koloniálnym dedičstvom.

Martího vlastná filozofická reflexia tak vychádza z uvedomenia si koloniálneho postavenia latinskoamerických štátov, ktoré negeneruje len politické a ekonomické dôsledky. Okrem politických otázok zameraných na revolučnú zmenu a vznik nezávislej republiky, vyvoláva stáročia trvajúci kolonializmus tiež pýtanie sa po identite moderného Američana. Tieto otázky si Martí kladie najmä tvárou v tvár sociálnej realite v latinskoamerických republikách. Zaujíma ho: Čo je to Amerika? Kto je Američanom? K čomu sa má hlásit' republika, ktorá sa oslobodí spod koloniálnej nadvlády? Na čo nadviaže? Kde bude hl'adat' pramene svojej identity? Tieto otázky vedú Martího $\mathrm{k}$ prehodnocovaniu filozofie, európskej filozofie a vplyvov, ktoré v danom geografickom prostredí v 19. storočí rezonovali. Martí si všímal rozpor európskej filozofickej tradície a reálneho spoločenského a kultúrneho ovzdušia v Latinskej Amerike. Práve ten sa stal živnou pôdou pre kritiku európskeho univerzalizmu vo filozofii, ktorá sa prejavila v Martího tvrdení, že filozofia nevznikla na Západe, ale na Východe. Martí prisudzoval rovnakú vážnost' formám myslenia, ktoré sa rozvíjali v Indii, Číne, Perzii, Egypte, atd'. (Martí 1991a, 359). Z tohto tvrdenia vyplýva, že filozofická reflexia je možná aj bez zväzku s európskou lokalizáciou. Táto téza sa stala pre Martího základňou, na ktorej mohol budovat' vlastnú perspektívu latinskoamerickej filozofie, ktorá by mala relevantné postavenie v spektre iných myšlienkových tradícií. Latinskoamerická filozofia by nemala podl'a Martího byt' učenou záležitost’ou, ako to je v prípade európskej filozofie, ale žitou praxou. Pre ignorovanie historických reálií a snahu abstrahovat' od konkrétneho sociálneho celku, odmietal Martí špekulatívnu európsku filozofiu 19. storočia. Podla neho boli podobné myšlienkové hnutia (ako napríklad nemecký klasický idealizmus) výsledkom odcudzeného a osamoteného subjektu stojaceho mimo sveta a dejín (Martí 1991b, 75). Oproti racionalistickej redukcii rozumu, ktorá je preňho stelesnená v abstraktnej metafyzike, obhajoval Martí tzv. „otvorený rozum“, ktorý sprevádza človeka na jeho ceste až k poznaniu univerza. Otvorenost' rozumu vedie $\mathrm{k}$ autonómii myslenia, ktorá sa prejavuje v schopnosti rozpoznat' a rešpektovat' iné formy vedenia. Martí zameral svoju pozornost' na typ myslenia, v ktorom teoretická reflexia nie je oddelená od žitej praxe. Vyjadril potrebu prepojenia filozofie s históriou, pričom väčšmi ako dejiny filozofie ho zaujímala funkcia filozofie a jej vplyv na dejiny a život človeka. Martího filozofický koncept prepája filozofiu s reálnou sociálnou praxou v zmysle schopnosti filozofie zasiahnut’ do reálnych spoločenských procesov. Vzt'ah k tradičnej filozofii bol preňho procesom rozpoznávania dvoch druhov filozofických prístupov. Prvým je tzv. „filozofia katedrových 
múmií“, erudovaných učencov, ktorí scholasticky reprodukujú myslenie. Abstrakciami sa odtŕhajú od reálneho spoločenského diania a tým strácajú kontakt so životom. Druhou je filozofia tých, ktorí tvoria, vynachádzajú riešenia problémov, ktoré nastol'ujú dejiny. Martí sa hlási práve k tomuto typu filozofie, ked' konštatuje, že „reprodukovat' nie je tvorit““ a že práve „tvorit’ je úlohou človeka“ (Martí 1991c, 370). Základnou funkciou filozofie v Martího interpretácii je dosahovanie spoločenského prospechu. V kontexte martíovského myslenia a daného historického ukotvenia autora je tento aspekt úzko spojený s funkciou oslobodzovania. Filozofia má byt' v kontakte s človekom, jeho potrebami, jeho žitou praxou. Má reagovat' na špecifické problémy a požiadavky amerického kontinentu, v prenesenom zmysle slova, špecifické podmienky akejkol'vek spoločnosti. Aby takouto mohla byt', musí sa zaoberat' výkladom dejín, musí zohl'adnit' kultúrne a historické špecifiká nie v univerzálnom meradle podl'a najvyspelejších krajín, ale musí rozpoznávat', skúmat' a poznat' problémy a požiadavky človeka a spoločnosti, v ktorej prostredí jestvuje. Východisko poznania pre praktickú filozofiu sa prejavuje v Martího požiadavkách po reforme vzdelávania. „Riešenie problému po poznaní jeho podstaty je jednoduchšie ako jeho riešenie bez tohto poznania. (...) Poznat' znamená riešit'. Poznat' krajinu a riadit' ju v súlade s týmto poznaním je jediný spôsob ako ju oslobodit' od tyranie. Európska univerzita musí ustúpit’ pred univerzitou americkou. Dejinám Ameriky od Inkov po súčasnost' sa musí vyučovat' podrobne, aj ked' sa nebude učit’ dejinám gréckych archontov. Naše Grécko má prednost' pred Gréckom, čo nie je naše. Je nám potrebnejšie“ (Martí 2005, 34).

Za základné aspekty Martího filozofie tak môžeme považovat' rovnost' (rasovú, etnickú, národnostnú), jednotu (prejavuje sa ako prakticky nevyhnutný prvok sociálneho boja proti kolonializmu) a dialogickost'. Jeho filozofia hladá prieniky medzi viacerými myšlienkovými i politickými prúdmi, snaží sa zmierňovat' rozdiely za účelom dosiahnutia spoločenského konsenzu a vzájomného rešpektu. Ten je predpokladom harmonického spolužitia stelesneného v Martího ponímaní v ideále republikánskeho zriadenia. Martího myšlienkový koncept, hoc je orientovaný na reálie amerických krajín, je uplatnitel'ný v ktorejkol'vek krajine. Martí rozvíja svoje východiská v problematizovaní spoločenských problémov rasizmu, kolonializmu, závislosti (ekonomickej, politickej i kultúrnej), pričom zdôrazňuje potrebu tvorby človeka ako prvého kroku spoločenskej emancipácie. Napriek tomu, že Martí písal o Amerike, vybrané črty jeho filozofie prechádzajú hranice tohto kontinentu. I preto Roberto Fernández Retamar konštatuje, že Martího hlas je prvým hlasom toho, čo dnes nazývame tretí svet (Retamar 1967, 19 - 60). 


\section{Boj o Martího, boj o Kubu, boj o Latinskú Ameriku}

„Konečne môžem napísat’ (...) Každú minútu môžem zomriet' za vlast', padnút' pri plnení svojej povinnosti (...) Musíme vydobyt' nezávislost' Kuby, lebo v inom prípade Spojené štáty obsadia Antilské ostrovy a odtial' vtrhnú na územie Ameriky. Všetko to, čo som doteraz urobil a všetko, čo ešte budem schopný urobit', som vykonal v záujme tohto ciela. Sú národy (medzi ne patria i naše národy), ktorých životným záujmom je, aby sa zahraniční imperialisti nedohodli so Španielmi a cez Kubu si neprekliesnili cestu, ktorá by umožnila krutému, agresívnemu Severu, tomu Severu, ktorý nami opovrhuje, anektovat' krajiny našej Ameriky. Musíme túto cestu prekazit' za každú cenu. My Kubánci ju zahatíme vlastnou hrud’ou. Spoločenské a miestne pomery zabránili bratským národom pripojit' sa k nám a rozdelit' sa s nami o obete, ktoré prinášame pre spoločné blaho, pre životné záujmy našej Ameriky. Žil som v lone netvora a poznám jeho vnútro; v rukách držím Davidov prak“ (Martí 1985b, 314). V poslednom nedokončeným liste svojmu priatelovi vyjadril Martí obavu z nasledovného vývoja na Kube a v Latinskej Amerike. Jeho varovanie nadobúdalo význam vo svetle okolností dobytia nezávislosti a s postupným neokoloniálnym vplyvom severného suseda sa stávalo aktuálnejším. Martí síce padol v bojoch za nezávislost' v roku 1895, avšak proces dobytia nezávislosti nabral na spáde až v roku 1898, kedy v havanskom prístave explodoval severoamerický krížnik Maine. USA obvinili z výbuchu Španielsko. Tento incident sa stal zámienkou pre vstup USA do bojov o nezávislost' Kuby. Spojené štáty využili svoju ekonomickú a vojenskú prevahu a v bojoch o Kubu Španielov porazili. Španielsko-americký vojenský konflikt je považovaný za prvé imperialistické militaristické vystúpenie, ked'že sa už bojovalo o územie sveta rozdelené medzi svetové vel'moci. $Z$ hl'adiska charakteru dobytej nezávislosti je výpovedným fakt, že ani jeden predstavitel' kubánskeho hnutia za nezávislost', či už jej civilného alebo vojenského krídla, nebol prizvaný k mierovým rokovaniam po ukončení vojny za nezávislost' Kuby vo Versailles. Po americkom vít’azstve nad Španielmi nasledovala štvorročná vojenská okupácia ostrova Spojenými štátmi, počas ktorých sa vybudovala úplná politická závislost' Kuby na USA, a boli položené základy i pre rovnako hlbokú závislost’ ekonomickú. 0 charaktere kubánskej suverenity vypovedá i podoba prvej kubánskej ústavy, do ktorej bol včlenený tzv. Plattov dodatok (platný do roku 1934). Smernica poskytovala Spojený štátom trvalé právo na intervenciu a vmiešavanie sa do vnútorných záležitostí krajiny. Dodatkom sa stanovovalo, že ostrovná vláda nesmie priznat’ zvláštne práva či privilégiá iným národom ani prijímat' pôžičky presahujúce jej predvídatel'né platobné možnosti. Dodatok 
predpokladal tiež uznanie všetkých zákonov vydaných okupačnou správou a ukladal Washingtonu úlohu intervenovat' v prospech zachovania kubánskej nezávislosti „života, slobody a majetku“ a v záujme zachovania stabilnej vlády (Trento 2006, 16).

Anticipácia vývoja v Latinskej Amerike vychádzala u Martího predovšetkým zo skúseností mladých republík v Latinskej Amerike a zo sledovania vývoja medzinárodnej situácie počas svojho pobytu v USA. Význam Martího myšlienok umocňovala mohutnejúca vojenská nadvláda USA na kontinente, ktorá sa prejavovala v početných vojenských intervenciách a okupácii štátov. Idea nezávislosti tak v Latinskej Amerike nezanikla so vznikom formálnych buržoáznych republík, ale stala sa centrálnou osou národnooslobodzovacieho hnutia najmä v druhej polovici 20. storočia. Bol to preto práve José Martí a jeho myšlienkové dedičstvo, ku ktorému sa už v roku 1953 pri výsluchu po neúspešnom útoku na kasárne Moncada pri Santiago de Cuba prihlásil Fidel Castro. Ideovo sa kubánska revolúcia hlásila k Martímu, k myšlienke nezávislosti a národného oslobodenia. Z hladiska taktiky kopírovala Martího víziu oslobodzovania ostrova - vylodením sa v provincii Oriente a stadial' realizovaním partizánskeho boja, prostredníctvom ktorého sa postupne oslobodzovalo kubánske územie. Po vítazstve revolúcie sa stal Martí ústrednou kultúrnou osobnostou kubánskych dejín. Inšpirácia kubánskou revolúciou, ktorá sa šírila na americkom kontinente sa okrem d’alších ideových vplyvov vracala tiež k ideálom José Martího.

V kontexte širšieho spektra spoločenských posunov v Latinskej Amerike je možné porozumiet' súčasným sporom o Martího. Po vít’azstve a udržaní kubánskej revolúcie sa začal tiež interpretačný spor o význam a obsah Martího diela. Hoci sa oficiálne Kuba prihlásila k myšlienkovému dedičstvu José Martího, opozičné sily vyčítali jeho zneužitie a kriticky sa stavali k interpretácii Martího diela v blízkej súvislosti s marxizmom. Súvislost' Martího diela, revolúcie na Kube a marxizmom vychádza zo špecifickosti latinskoamerickej situácie v polovici 20. storočia spätej s formovaním sa národnooslobodzovacieho hnutia v tomto regióne. Na vysvetlenie tejto situácie je potrebné objasnit' vztahah Martího filozofie k marxizmu, špecifické ideové ukotvenie národnooslobodzovacieho hnutia na Kube (podobné d’alším krajinám v Latinskej Amerike) a napokon zamerat' pozornost' na význam interpretačných sporov o Martího z hladiska aktuálnej sociálnej situácie v Latinskej Amerike.

Hoci sa Martí k marxizmu nehlásil, možno v prístupoch oboch autorov sledovat' niektoré spoločné črty. Rovnako Martí ako i Marx zdôrazňujú praktickú rovinu filozofie. U Marxa je vyjadrená (okrem iného) tézou, že „filozofi doteraz svet len rozlične vysvetlovali, ide však o to zmenit' ho" 
(Marx 1977, 211) ekvivalentne u Martího je „konanie lepším spôsobom hovorenia“. Prostriedkom sociálnej praxe je v oboch koncepciách revolúcia. Pokým však Marx hovorí o socialistickej revolúcii a zmene spoločensko-ekonomickej formácie, Martí sa zameriava na buržoázno-demokratickú revolúciu, ktorej cielom je zmena formy vlády stelesnená v nastolení republiky. Tieto odlišnosti akiste vyplývajú z vývojových špecifík odlišných geografických prostredí oboch autorov. Hoci Marx nebol marxista a presadzoval projekt buržoázno-demokratickej revolúcie, nemožno ho považovat' za autora ukotveného v buržoáznej matrici uvažovania. Aj ked' jeho kritika sociálnych podmienok vytváraných kapitalizmom nesmeruje k zničeniu buržoázneho systému, situuje ho nad jednoduché reformistické ideály prezentované inými americkými filozofmi jeho doby. Martí nesúhlasil s buržoáznym myslením dominantných skupín, pretože jeho reflexia vychádzala $\mathrm{z}$ ašpirácií utláčaných - indiánov, mesticov, černochov, rol'níkov a robotníkov. Pritom však, ked' hovoril o utlačovatel'och a utláčaných neuplatňoval triedny pohlad, a teda nemal na mysli buržoáziu a proletariát, ale kolonizátorov a kolonizovaných. Napriek tomu sa identifikoval s robotníckym problémom a akceptoval metódy robotníkov na oponovanie voči nespravodlivosti „pánov“. Žaloval obchodnú tyraniu stelesnenú vzrastajúcim vplyvom monopolov a odsudzoval katastrofálne spoločensko-ekonomické dôsledky tohto procesu. Podla Martího „monopol sedí ako nezmieritel'ný gigant na bráne všetkých chudobných“ (Martí 1991e, 84). Martí rozpoznával príčiny chudoby a marginalizácie väčšiny obyvatel'stva ako dôsledky koloniálnej závislosti. Uvedomoval si zároveň, že kolonializmus sa neodstráni volaniami po morálnom uvedomení kolonizátorov, ale len otvorenou vojnou - revolučným bojom proti panujúcemu systému. V prístupe k sociálnemu problému vnútri národného kontextu však rovnaký princíp radikálnej demarkácie záujmov neaplikoval. Zdôrazňovanie jednoty v spoločnom boji za oslobodenie sa z pút kolonializmu mu bránilo nazerat' na sociálne problémy svojej doby, ktoré sledoval, vnímal a zastával v nich tých najchudobnejších, ako na problémy konfliktu triednych záujmov, ktoré sa vyskytovali aj v jednom národnom celku. Dôležité bolo preto preňho vytvorenie silného morálneho vedomia, štedrej a spravodlivej harmónie, bez rozdel'ovania sa a v záujme všetkých.

Rovnako ako sa Martí za svojho života nehlásil k marxizmu, ani kubánska revolúcia sa do roku 1961 nedefinovala ako socialistická. Ideovo sa hlásila k Martího kritike kolonializmu, upozorňovala na pretrvávajúcu závislost' a rozpory oficiálne deklarovaných hodnôt a princípov so žitou praxou Kubáncov. Socialistickou sa kubánska revolúcia stala v postupnom vývoji konkrétnej historickej praxe. Podobný vývoj sledujeme v d’alších krajinách regiónu (Chile, Nikaragua, Grenada, Venezuela). Národnooslobodzovacím 
hnutiam v Latinskej Amerike nepredchádzala teoretická marxistická báza. Aj ked' sa nedefinovali ako socialistické revolúcie, socializmus sa stal logickým vyústením snáh oslobodit' sa spod imperialistickej neokoloniálnej závislosti charakteristickej pre daný región už od konca 19. storočia a vrcholiacej v 50. rokoch 20. storočia. Kubánska revolúcia počas prvých rokov procesu, v ktorom sa postupne utváral jej socialistický charakter postavila revolučný program, ktorý chápe problém kolonializmu, imperializmu, utvárania národa, oslobodenia utláčaných a konštrukcie socializmu ako neoddelitel'né súčasti jedného sociálneho boja. Jeho výsledkom je socialistická spoločnost', ktorá sa nemusí nevyhnutne chápat’ ako kópia socialistickej spoločnosti vybudovanej na základe príkladu inej krajiny, ale socializmu, ktorý vzíde z konkrétnej historickej reality Latinskej Ameriky (Mariátegui, 1969, 111 - 112). Vztah utvorenia socializmu a požiadavky suverenity Latinskej Ameriky je vnímaný ako vzájomný. Interpretácia spoločenských pomerov, ktorú na začiatku 60. rokov iniciuje kubánska revolúcia vychádzala z predpokladu, že socialistický poriadok umožní rozvoj vlastnej identity a dôstojnej existencie populácii Latinskej Ameriky. Problém l'udu a národa sa tak zdal byt' riešitel'ný jedine prostredníctvom socializmu. Tento argument zastával Ernesto Guevara, ktorý v roku 1967 reagoval na rovnaké požiadavky (národnej suverenity a nezávislosti) v politických programoch amerických buržoáznych strán. Podla neho boli národné buržoázie neschopné odporovat' severoamerickému imperializmu, čo považoval za fakt nútiaci k rozhodnutiu o charaktere akéhokol'vek revolučného procesu v 20. storočí. Tvrdil, že národnooslobodzovacia revolúcia môže byt' bud' socialistickou, alebo karikatúrou revolúcie (Guevara 2005). Program kubánskej revolúcie nadväzuje na Martího kritiku kolonializmu, poukazuje na historické reálie svedčiace o pokračujúcej koloniálnej závislosti realizovanej pod rúškom formálnej nezávislosti a v politickom rámci republikánskeho zriadenia a svoj boj proti tejto závislosti v procese vývoja definuje ako boj za socializmus. Tým sa v období bipolárne rozdeleného sveta Kuba pripojila k socialistickým krajinám a stala sa prvou socialistickou krajinou na západnej pologuli.

Ekonomické sankcie, snaha o medzinárodnú diplomatickú izoláciu Kuby, početné sabotáže a organizovanie anticastrovskej propagandy a diverznej činnosti, nevylučujúc ani otvorenú vojenskú agresiu v apríli roku 1961 zo strany USA je možné v teoretickom rámci ponímat' ako aspekty triedneho boja. Tento praktický boj sa realizuje tiež na poli ideológie, kultúry či literatúry, kde doň aktívne vstupujú interpretácie filozofických diel a myšlienkových tradícií mnohých autorov. Martí je tak interpretovaný z hladiska triedneho vztahu pre buržoáziu ako filozof, ktorý bol zneužitý kubánskou revolúciou, ktorá sa neoprávnene zastrešila jeho ideálmi; 
pre proletariát resp. z hl'adiska pohl'adu socialistickej Kuby, je ponímaný ako Apoštol kubánskej revolúcie, ktorého ideály o nezávislej Kube sa Kubáncom od roku 1959 darí napín̆at'. Triedny prístup (hoc nebol vlastný Martímu) je možné uplatnit' pre vysvetlenie aj súčasných spoločenských posunov v Latinskej Amerike. Vandalizmus Martího sôch a búst, masívna strel'ba na zastupitel'ský úrad Kuby vo Washingtone 30. apríla 2020 a (zatial') neúspešné dovolávanie sa kubánskej strany jej objasnenia ako i d’alšie skutky namierené proti súčasnej politickej línii Kuby tak možno vnímat' ako aspekty vzájomného boja spoločenských skupín reprezentujúcich odlišné záujmy. V Martího ponímaní ich možno vnímat’ ako snahy záujmov severoamerických monopolov uzurpovat' a vykorist'ovat' územie „našej“ Ameriky.

\section{Záver}

Za základné aspekty Martího filozofie môžeme považovat' snahu o zmier, dialóg a jednotu. Martí vystupoval proti rasovej, etnickej a národnostnej nadradenosti a presadzoval projekt slobodných spoločností zbavených kolonializmu. Vzájomný rešpekt, akceptácia kultúrnej a názorovej inakosti sa vyjadrovala v jeho dôraze na jednotu. Samotný obsah diela tohto básnika, literáta a filozofa, ktorý vstúpil na scénu praktických sociálnych bojov na konci 19. storočia, a ktorý v nich pred 125. rokmi padol, je v zhode s oficiálnym politickým a spoločenským kurzom súčasnosti. Preto protichodné reakcie na Martího dielo vyvolávajú viaceré otázky. V duchu martíovskej tradície sú bez ich ukotvenia v konkrétnych historických okolnostiach neriešitel'né. Preto z hl'adiska porozumeniu Martího dielu je prínosné zamerat' sa na jeho vlastný filozofický odkaz, no zároveň zohl'adnit' historické súvislosti národnooslobodzovacích hnutí, ktoré sa ideovo odvolávali (aj) na Martího filozofiu, a ktorých vrcholom bola práve kubánska revolúcia. Do teoretických sporov o Martího sa premietajú praktické sociálne zápasy o charakter Kuby a vôbec latinskoamerického regiónu. Zároveň podoba súčasných sporov o Martího poukazuje na komplikovanost' vzt’ahu teoretickej bázy akcentujúcej rovnost', medzil'udský rešpekt a toleranciu (vlastné dielu José Martího) s praktickou sociálnou realitou. Prístup k Martímu tak okrem iného odhal'uje vnútorné rozpory súdobej spoločnosti, nekompatibilitu deklarovaného sociálneho zámeru so sociálnou praxou.

\section{Literatúra}

AREGO, A.:Vandalizan estatuas de José Martí en La Habana. Web. 16. 5. 2020.

https://www.cibercuba.com/noticias/2020-01-02-u199291-e199291s27061-vandalizan-estatuas-jose-marti-habana

DINUŠOVÁ, D. (2018) : Za hlasom revolúcie. Bratislava: Veda. 
Gobierno cubano vincula el embargo con atentado a su embajada en Washington. CiberCuba. Web. 30. 5. 2020. https://www.cibercuba.com/noticias/2020-0529-u1-e43231-s27061-gobierno-cuba-vincula-al-embargo-atentado-contrasu-embajada

GUEVARA, E. (2005): Mensaje a la Tricontinental. In: HART, A.: Marx, Engels y la condición humana. Una visión desde Cuba. La Habana: Antología, desde 1909 hasta nuestros días (Edición actualizada).

FORNET-BETANCOURT, R.: El pensamiento de José Martí. In Ensayistas. Web. 20. 8. 2016. http://www.ensayistas.org/filosofos/cuba/marti/marti8.htm

MARIÁTEGUI, J.C. (1969): Mensaje al Congreso Obrero. In: Ideología y Política. Vol. 13. Lima: Editora Amauta.

MARTÍ, J. (1985a): Manifest z Montecristi. In: Moje Amerika. Praha: Odeon.

MARTÍ, J. (1991a): Filosofía. In: Obras completas, Vol.19, Viajes/Diarios/Crónicas/ Juicios. La Habana: Editorial de Ciencias Sociales.

MARTÍ, J. (1991b): Cuaderos de Apuntes, Cuaderno No. 2. In: Obras completas Vol. 21, Cuadernos de Apuntes. La Habana: Editorial de Ciencias Sociales.

MARTÍ, J. (1991c): Fiesta de la Liga de Propiedad Literaria. El Partido Liberal 1888. In: Obras completas. Vol 11. Escenas norteamericanas III. La Habana: Editorial de Ciencias Sociales

MARTÍ, J. (1991d): Carta de Martí. Nueva York, 29. de marzo de 1883. In: MARTÍ, J.: Obras completas, Vol 9. En los Estados unidos. La Habana: Editorial Ciencias Sociales.

MARTÍ, J. (1991e): Filiación política. El origen del Partido Reublicano de los Estados Unidos, La Nación, 6. de noviembre de 1884. In: MARTí, J.: Obras completas, Vol. 10, En los Estados Unidos. Escenas norteamericanas I-IV. La Habana : Editorial de Ciencias Sociales.

MARTÍ, J. (2005): Nuestra América. In: Nuestra América. Caracas: Biblioteca Ayacucho.

MARTÍ, J.(1985b): List Manuelu Mercadovi z 18. mája 1895. In: MARTÍ, J.: Moje Amerika. Praha : Odeon.

MARX, K. (1977): Tézy o Feuerbachovi. In: MARX, K. - ENGELS, F.: Vybrané spisy v piatich zväzkoch. Zv. 1, Bratislava: Pravda.

RETAMAR, R. F. (1967): Martí en su (tercer) mundo. In: Ensayo de otro mundo. La Habana.

TRENTO, A. (2006): Castro a Kuba. Od revoluce k dnešku. Praha: KMa.

\section{Mgr. Dominika Dinušová, PhD.}

Katedra spoločenských vied

Akadémia Policajného zboru v Bratislave

Sklabinská 1, 83517 Bratislava

dominika.dinusova@akademiapz.sk 


\section{ALAIN DE BENOIST. Být pohanem.}

Zvolen: Sol Noctis 2019, 278 s.

Kniha Byt' pohanom bola vydaná vo Francúzsku v roku 1981. Jej preklad teda prichádza so značným oneskorením. Autor vyštudoval na Sorbonne právo, filozofiu, sociológiu a dejiny náboženstva. Tiež je známy ako zakladatel' francúzskeho Združenia pre výskum a štúdium európskej kultúry. Publikácia je rozdelená do dvadsiatich šiestich kapitol a Benoist v nej chce písat' o dvoch vel'kých pohladoch na svet, o dvoch duchovných víziách pohanskej a náboženskej. Benoist sa v knihe venuje mnohým témam: dejinám, stvoreniu, l'udskej prirodzenosti, mesianizmu, estetickým otázkam, sexualite, božskej imanencii a l'udskej transcendencii, politike, a d’alším. Vykladá judeo-krest’anský postoj a konfrontuje ho s pohanským nazeraním na skutočnost'.

Pohanstvo chápe francúzsky autor ako pôvodné náboženstvo Európy, ktoré ho prit’ahuje, pričom krest'anské resp. biblické myslenie ho odpudzuje. Pohanstvo nikdy nezomrelo a na konci 20. storočia je opät' pre množstvo liudí prítažlivé. Je to myslenie, ktoré odmieta monolineárnu historickú perspektívu, v ktorej sa minulost' už nemôže vrátit', ale verí vo večný návrat a v nový začiatok. Novopohanstvo je „vedomá vol'ba autentickejšej, harmonickejšej a slávnejšej budúcnosti - vol'by premietajúcej sa do budúcnosti, pre nové výtvory, Večnost', z ktorej pochádzame“ (s. 35). Podstatným znakom pohanského myslenia je sakralizácia sveta a tým jeho povýšenie, zatial čo judeo-krestanský prístup je ústupom, stiahnutím sa z tohto sveta. Pohanstvo stojí na idey sakrálneho. Medzi jeho klúčové hodnoty patria etika založená na cti, heroický postoj k výzvam života, pozdvihnutie a sakralizácia krásy, tela, sily a zdravia.

Z môjho pohl'adu je problematické vyjadrenie týkajúce sa dualizmu v krest'anstve (s. 48-49), či samotné chápanie dualizmu. Benoist tvrdí, že krestanstvo predstavuje najradikálnejšiu formu dualizmu tým, že radikálne rozlišuje medzi svetom a Bohom. Z krestanskej perspektívy sa však v žiadnom prípade o dualizmus nejedná, nakol'ko Boh a svet nestoja oproti sebe ako dva večné, protikladné ontologické princípy.

Autor v knihe rozvádza a obhajuje tézu, že Zákon, ktorý Boh stanovil človeku, je pre človeka obmedzením. Judeo-krest'anský monoteizmus tak vyvinul negatívnu antropológiu, pretože je to negatívne náboženstvo, či dokonca anti-náboženstvo. Človek už nie je súdený v súlade so svojimi vlastnými zákonmi, ale v súlade so zákonmi Absolútne Iného. Vzostup krest’anskej morálky môžeme vnímat’ ako ústup životnej energie a ničenie životnej sily. Okrem toho samotný fakt ustanovenia niečoho Absolútne 
Iného vedie k umenšeniu významu Iného, kde Iné je vymazávané, odmietané, vylučované; je to popieranie Iného a cudzieho. Odvolanie na Jahveho znamená zastávat' presvedčenie o falošnosti iných, ich hodnôt, životných štýlov a svetonázorov. Monoteizmus ako taký je negatívny, nakol'ko nevedie človeka k sebaprekonaniu, ale požiera jeho vitalitu. Na rozdiel od neho pohan je zástancom odvahy, intenzity a prúdu života.

Významným prvkom pohanstva je tolerancia - akceptovanie množstva rozličných bohov, ich foriem uctievania, plurality mravov, sociálnych a politických systémov, odlišných koncepcií sveta. Pohanstvo je tolerantné nielen preto, lebo je (potenciálne) polyteistické a tým pluralistické, ale tiež preto, že nie je dualistické. Odmieta diskontinuitu Boha a sveta a oproti nej stavia koncepciu dialektickej kontinuity všetkého (ludí, bohov, prírody), čo predstavuje jediné ucelené bytie.

Iba človek je bytost'ou, ktorá si kladie otázku o bytí. Je to fundamentálna otázka, nevyhnutná pre „prebudenie ducha“, ktorý je ohrozený úzkostou. Otázka „prečo existuje skôr niečo a nie nič?“ je z hladiska krest’anskej viery nemyslitel'ná, nekladie sa, pretože odpoved' je už a priori daná Bohom, odpoved' retroaktívne zabraňuje položeniu otázky (s. 268). Benoist odkazuje na viaceré Nietzscheho a Heideggerove myšlienky, vrátane myšlienky iného, nového počiatku. Tento počiatok je opustením jednej podoby metafyziky v prospech myslenia, ktoré Boha podriadi bytiu ( $\mathrm{v}$ rámci zjednotenej štvorice zeme, oblohy, človeka a Boha). Nový počiatok je spojený so založením novopohanstva, umožňujúceho realizáciu autentického života.

Zaiste viacero čitatel'ov nebude súhlasit' s jeho interpretáciami krest’anstva a biblického myslenia. Krestanský čitatel' bude tvrdit', že krest’anstvo je tu interpretované inak, než chápe ono samo seba. V každom prípade Benoist dobre demonštruje, ako a prečo je biblické myslenie pre pohanstvo nezrozumitel'né, neprijatel'né, priam odpudzujúce. Jeho kniha zvýrazňuje a necháva vidiet' protiklady dvoch nezlučitel'ných pohl'adov na skutočnost' a dvoch odlišných skúseností, ktoré - a smieme to zaiste vyslovit' - si nikdy nebudú rozumiet'.

Text francúzskeho myslitel'a nesporne vyvolá v čitatel'ovi viacero otázok. Uvediem tie, ku ktorým jeho kniha inšpirovala mňa. Je dôležité dnes obhajovat' svoje hodnoty a svoj názor (pohanský, krestanský, agnostický, atd'.)? Aký je, resp. aký bude dôsledok tejto obhajoby? Bude výrazom dialógu, vzájomného porozumenia a zblíženia sa rozličných názorových perspektív? Alebo vytvorí medzi rôznymi stranami ešte väčšiu priepast'? Príde po týchto obhajobách k určitým menším či zásadným zmenám v postojoch alebo zostane zachovaný status quo? Je vhodnejšie o istých otázkach a názoroch skôr nehovorit', ako ich obhajovat'? Môže byt' toto mlčanie 
a nehovorenie viac pozitívne ako obhajoba vlastného názoru? Ako konat' v dnešnej situácii vtedy, ked' sú v spore náboženské a pohanské hodnoty?

Recenzovaná publikácia je dobre čitatel'ná a vel'mi vhodná pre univerzitných študentov religionistiky, filozofie, politológie, sociológie, histórie. Pomáha spoznat', resp. obnovit' si poznatky o podstate pohanstva: čo vlastne znamená byt' pohanom, prečo sa rozhodnút' pre túto vol'bu, prečo ju obhajovat’ a v čom spočíva zásadná odlišnost' pohanstva od náboženského postoja. Z týchto dôvodov možno knihu nesporne odporučit'.

Martin Vašek

doc. Mgr. Martin Vašek, PhD.

Katedra filozofie

Filozofická fakulta

Univerzita Konštantína Filozofa v Nitre, SK

Hodžova 1

94974 Nitra

mvasek@ukf.sk 